\title{
Risk Factors Related to Juvenile Drug Use
}

\author{
Eglantina Dervishi \\ University of Tirana, Faculty of Social Sciences \\ Department of Psychology and Pedagogy \\ Silva Ibrahimi \\ Albanian University, Faculty of Social Sciences, Tirana \\ Department of Psychology and Research Center
}

Received 13 June 2018 • Revised 25 September 2018 • Accepted 10 October 2018

\begin{abstract}
The aim of this study was to explore the prevalence of drugs abuse in the juvenile prison taken from pre-trial detention and Penitentiary Institution of the Albanian Country and to examine some evidence between criminal behavior and use of drugs by juvenile offenders. This research is an exploratory one, and tries to determine a link between criminal behavior and drugs. The target population consists of 71 imprisoned juveniles aged from 14 to 18 in four prisons in pretrial detention and prison institutions in Albania. For the entire population of males and females offenders interviews are used, due to their small numbers. Direct interviewing was managed by trained interviewers at a time and place convenient to the prison system and insuring the confidentiality of the offenders' responses. Analyses reported in the present study involve simple descriptive statistics from Univariate Analysis to describe the central tendency of mean, mode, median, range, variance, max, min, standard deviation and percentages. Juvenile offenders who experiment with drugs, report episodes of offending, especially physical assault, robbery and stealing either those who were in detention for the first time or recidivists in crimes. An important finding is related to the onset of first offense among the juveniles. The mean age of first offending suggests that young males under the age of 16 years are at increased risk of criminal offending. Almost all offenders reported having used marijuana or alcohol, a percent reported crack cocaine use at the age of 11-14 years old. It is important to establish that not all drug users are criminals, and not all criminal acts are committed by drug users. However, the study highlight certain issues that need attention of country policy-makers. Juveniles are heavy users of marijuana and according to the present research, typically began their marijuana use at around the age of fourteen.
\end{abstract}

Keywords: juvenile, drug use, pre-trial detention, sentenced.

\section{Introduction}

Substance abuse remains an issue which is quite difficult to deal with (Kenneth et al., 2018), during its withdrawn process (Kenneth \& Botvin, 2011). Referring to the term "abuse of narcotic substances", we consider the use of alcohol, tobacco, marijuana and other forms of synthetic drugs by the adolescent. It is either considered as an issue of mental health (Childs \& Sullivan, 2013) and as such is addressed in a multidisciplinary team. Substance abuse does not

(C) Authors. Terms and conditions of Creative Commons Attribution 4.0 International (CC BY 4.0) apply. Correspondence: Eglantina Dervishi, Bulevardi "Gjergj Fishta", Tirana, ALBANIA. E-mail: egladervishi@gmail.com. 
only affect the abusive individual (DeLisi et al., 2015), but also has an extension to the family, society, school and community (Brook et al., 2013) where the user lives. It seems that the most vulnerable category to fall a prey to drug abuse (Burnhams, 2016) remains the adolescence. Drug use in a teen age (Averdijk et al., 2016) has long and short-term consequences in the user's life. An element that is believed to link narcotic drug users is their involvement into illegal activities as a source of drug purchasing (Brook et al., 2006) or acting under their effects (Ramsoomar, 2015). Referring to studies on the risk factors for substance abuse, there could be included a series of factors that can interact alone or with one another. Socio-economic factors (Botvin et al., 1995) seem to play a major role in the drug use matters.

There is a connection between lower socio-economic status (Magidson et al., 2016) and drug use growth. Children grown in families living in a lower socio-economic status, especially whose parents, work for a minimum wage (Ennett, 2008) exhibit little care and supervision that can push their children to drug abuse problems. Communities with a lower social economic status are characterized by high unemployment (Kadalie \& Thomas, 2013), drug use, easy drug finding and criminality.

But other factors can also make the situation threatening, such as physical and mental health disorders (Merrill et al., 1999), including self-mutilation and suicidal behaviors, poor education, adolescent friendships with problematic and violent family history of drug abuse and alcohol adults (Catalano et al., 2002). Another risk factor relates to school (Eggert et al., 2001) and its role in order that the adolescent be able to manage his aggressive behavior or be protected from peers abuse form or even from teachers in some cases.

Coping with academic failures and finding sustainable forms of improvement in academic achievement (Matthews, Griggs \& Caine, 1999) can help teenagers not to undertake the decision (Broadus et al., 2010) to leave school. It is suggested by the researchers that the school, the decision to expel a teenager from school due to behavioral problems (Choi et al., 2012) can be managed more carefully (Kenneth \& Botvin, 2011). Researchers have suggested that adolescents drug users tend to be easily involved in criminal activity (Akers, Sellers \& Jennings, 2016) and in a variety of other serious behaviors forms (Agnew, 2015).

But even the adolescent period is likely to develop transitional dynamics (Poundall, Bogdanovica \& Langley, 2018) that increase the adolescent's uncertainty (Agnew, 2006) in relation to his status (Francis, 2014) both inside and outside the family. It seems that puberty with changes in physical development or social conditions related to the relocation of the family from one area to another, the divorce of the parents, during the period where the children begin to exhibit a higher vulnerability toward behavioral problems. The aim of the research is to give the opportunity of exploration of these factors based on how adolescents perceive them.

\section{Method}

Through an explorative study is aimed to define the links between criminal behavior and drug abuse in four institutions, 3 detention centers, concretely two in the city of Tirana and one in Durres, and the juvenile prison in Kavaja. Data were collected during the February-May 2017 period. The overall objective of the study was to determine the prevalence between the use of juvenile substances and the analysis of the link between criminal behavior and drug use as perceived by the adolescent. However, we would like to emphasize that it is not intended to determine the link between substance use and criminal behavior. 94\% males.

Relating the research sample, it consisted of 71 juveniles, of whom $4 \%$ were female and 
Table 1. Demographic data for gender

\begin{tabular}{|c|c|c|c|c|c|}
\hline \multicolumn{6}{|c|}{ Gender } \\
\hline & & Frequency & Percent & Valid Percent & Cumulative Percent \\
\hline \multirow[t]{3}{*}{ Valid } & Girls & 3 & 4.22 & 4.22 & 4.22 \\
\hline & Boys & 68 & 94.4 & 94.4 & 100.0 \\
\hline & Total & 71 & 100.0 & 100.0 & \\
\hline
\end{tabular}

\section{Instrument}

Data collection was developed through a pre-encoded interview that allowed us to collect information about the following dimensions:

- The socio-demographic data of the studied population;

- Their legal status;

- The use of drugs before imprisonment, the impact on imprisonment and the connection with violence before and during imprisonment;

- Changes in obtaining it while in jail;

- The link between crime and drug use, its classification.

The history of criminality for every convict who took part in the study

Interviews' data were transcripted using the Excel program and then imported into the SPSS.18 statistical program.

\section{Data analysis}

Types of performed analyzes included descriptive statistics, mean, median-range, variance, max, min, standard deviation and percentage statistics.

\section{Results}

Referring to the statistics of the General Pennintentiary Directorate, it appears that the number of juveniles involved in criminal offenses has increased from year to year. Referring to the demographic data on the settlement, it results that juveniles belonging to urban areas have the highest proportion of juvenile prisoners.

Table 2. Demographic data

\begin{tabular}{|c|c|c|c|c|c|}
\hline \multicolumn{6}{|c|}{ Location } \\
\hline & & Frequency & Percent & Valid Percent & Cumulative Percent \\
\hline \multirow[t]{3}{*}{ Valid } & Rural Areas & 29 & 45.8 & 45.8 & 45.8 \\
\hline & Urban Areas & 42 & 54.2 & 54.2 & 100.0 \\
\hline & Total & 71 & 100.0 & 100.0 & \\
\hline
\end{tabular}

Referring to the statistics of the General Penitentiary Directorate it is revealed that the number of juveniles involved in criminal offenses related to the use and use of narcotic drugs has increased. 
Table 3. Number of juveniles in penal I.E.V., May 2017

\begin{tabular}{|l|c|c|}
\hline Institution & Detained & Sentenced \\
\hline Kavaja & 19 & 21 \\
\hline Tirana & 18 & - \\
\hline Durres & 13 & - \\
\hline
\end{tabular}

Source: General Penitentiary Directorate

Referring to statistics at the national level, the largest number of criminal offenses involving juveniles are in the two main cities of Tirana and Durres. This evidence was provided by juveniles serving the sentence or are under trial at the Institution of Execution of Criminal Decisions in Kavaja, which is the only penitentiary institution for juveniles in the Republic of Albania.

Table 4. Type of crimes committed by juveniles, 2015-2017

\begin{tabular}{|l|c|c|c|}
\hline \multicolumn{1}{|c|}{ Types of crime } & 2015 & 2016 & 2017 \\
\hline Unauthorized possession of weapons & 18 & 18 & 25 \\
\hline Injury & 8 & 20 & 14 \\
\hline Trafficking and Use of Narcotic Substances & 17 & 21 & 25 \\
\hline Theft & 51 & 31 & 65 \\
\hline Weapon theft & 9 & 12 & 6 \\
\hline Violent theft & 19 & 18 & 8 \\
\hline Attempted Theft & 2 & - & 6 \\
\hline Theft in collaboration & 56 & 75 & 36 \\
\hline Murderer & 10 & 3 & 10 \\
\hline Attempted Homicide & 3 & 1 & 4 \\
\hline Rape of the graves & - & - & - \\
\hline Sexsual/homosexsual relations with minors & 3 & 9 & 8 \\
\hline Laundry of criminal offense products & 1 & - & - \\
\hline Threat for not denouncing crime & 2 & - & - \\
\hline Light criminal offenses & - & - & 7 \\
\hline Source: General Penitentiary Directorate & & & \\
\hline
\end{tabular}

This evidence can be argued by the fact that after the 1990s' there has been a large population shift in these two cities in almost from all Albanian areas. Referring to the general data, the majority of the juvenile are involved in criminal acts against property and less against the person. It is noted that the offenses committed by juveniles are mostly thefts, according to the Criminal Code classifications. In addition, the growth of juveniles who commit the criminal offense of narcotics distribution or use is of a great concern, especially in recent years.

\section{The history of criminal behaviors}

If we look at the data, it is revealed out that the theft and theft in co-operation are the two types of criminal offenses we have and the largest number including the juvenile. Another interesting fact worth discussing is the fact that the biggest number of juveniles in the last year was found to be unauthorized weapons and trafficking and use of narcotic drugs.

The prevalence of using narcotic substances referring to self-report questionnaire.

Referring to the data on the use of narcotic substances by juveniles by the type and age when they started using drugs, it results that tobacco and marijuana are among the two narcotic substances that are used in the highest percentage of juveniles and that the age of commencement 
of use starts early, around 11-13 years, it is also reported that both alcohol and Crack were used by youth of this age.

Table 5. Type of drug used by age when experimenting for the first time

\begin{tabular}{|c|c|c|c|c|c|c|}
\hline \multicolumn{7}{|c|}{ Descriptive Statistics } \\
\hline \multicolumn{2}{|l|}{ Age } & $\mathrm{N}$ & Minimum & Maximum & Mean & Std. Deviation \\
\hline \multirow[t]{5}{*}{$11-13$} & Marijuana & 39 & .86 & 2.43 & 3.6500 & .48050 \\
\hline & Alcohol & 39 & 1.00 & 3.57 & 2.9330 & .70125 \\
\hline & Tabacco & 39 & 1.60 & 3.80 & 4.9000 & .61171 \\
\hline & Krack & 39 & 1.30 & 3.60 & 2.6700 & .54396 \\
\hline & Valid N (listwise) & 39 & & & & \\
\hline \multirow[t]{5}{*}{$14-16$} & Marijuana & 32 & 1.00 & 3.47 & 2.4530 & .70225 \\
\hline & Alcohol & 32 & 1.50 & 3.70 & 2.2300 & .51171 \\
\hline & Tabacco & 32 & 1.70 & 3.30 & 1.9040 & .41171 \\
\hline & Krack & 32 & 1.00 & 3.50 & 1.6740 & .53396 \\
\hline & Valid N (listwise) & 32 & & & & \\
\hline
\end{tabular}

Whilst in the other 14- to 16-year groupage, marijuana and alcohol are seen as forms that are often experimented with by teens. From the data collected through self-report surveys, it is seen that juveniles have their own perception of risk factors related to the use of narcotic substances. Teens (21.7\%) think that drug injection and use are real-risk behaviors. But even though they see it as threatening, among $62.7 \%$ of them consider substance use necessary, feeling helpless to withdraw from.

About $37.3 \%$ of adolescents think that substance use has had a detrimental effect on their education, their relationships with others (inhere referring mostly to relationships with family members which have been affected as a result of their problems with the use of narcotic substances such as tobacco, alcohol, marijuana) and everyday life.

They report that their daily routine changed dramatically after the drug use began, some of them reported that they were like fuzzy and were not able to provide much information about what they remembered in these stages. Another interesting report referring to the perception of juveniles on the possible causes of criminal offenses were to obtain or buy drugs (47.4\%).

Table 6. Self-reports of minors on their perception of risk factors related to drug use

\begin{tabular}{|l|c|c|c|c|c|}
\hline Risk factors connected to drug use & $\mathrm{N}$ & Frequency & Percent & $\begin{array}{c}\text { Valid } \\
\text { Percent }\end{array}$ & $\begin{array}{c}\text { Cumulative } \\
\text { Percent }\end{array}$ \\
\hline $\begin{array}{l}\text { Behaviors that put the minor at real } \\
\text { risk (drug injecting/use) }\end{array}$ & 71 & 21 & 1.07 & 1.07 & 1.4 \\
\hline $\begin{array}{l}\text { Considers the use of substances a } \\
\text { necessity }\end{array}$ & 71 & 62 & 19.3 & 19.3 & 6.2 \\
\hline $\begin{array}{l}\text { Harmful effects on education / } \\
\text { relationships / everyday life }\end{array}$ & 71 & 37 & 9.3 & 9.3 & 39.0 \\
\hline $\begin{array}{l}\text { Has committed criminal offenses to } \\
\text { provide/buy drugs }\end{array}$ & 71 & 47 & 12.4 & 12.4 & 67.4 \\
\hline \begin{tabular}{l} 
Has traded/exchanged drugs \\
\hline $\begin{array}{l}\text { Other drug-related behaviors } \\
\text { (criminal behavior, fraud) }\end{array}$
\end{tabular} 71 & 45 & 11.8 & 11.8 & 81.4 \\
\hline
\end{tabular}


Of the juveniles involved in the study, $45.8 \%$ of them reported being involved in drug trading and drug trafficking. And 54.2\% of them revealed their involvement in drug-related behaviors such as robbery and fraud.

Referring to the data on the level of education, it results that $5 \%$ of them did not have any school class, $14 \%$ had only completed elementary education, $68 \%$ had completed the 9-years secondary education and only $13 \%$ had begun secondary education although not all had completed it. Referring to the reasons that teens revealed on the possible causes of the school termination, it is shown that $13 \%$ of them were excluded, $10 \%$ reported being forced to leave school as for family problems and $12 \%$ associate school dropouts with economic problems.

While $30 \%$ relate the issue to emigration and they said they left school because they wanted to leave the country, $21 \%$ of juveniles bring about learning difficulties, $2 \%$ refer to peer conflicts and $8 \%$ to conflicts with teachers. Distance of school from juvenile dwelling is reported by $2 \%$ of them and health issues from the $2 \%$ of teens.

\section{Conclusions}

It's not easy to be a teenager in our country. It seems that the political situation of the last few years makes it easier to deal with narcotic substances. On the other hand, the family and school institutions are not playing their role properly in terms of support and non-abstinence of the teenager adrift. Two of the cities that represent the highest levels of criminal behavior involving juveniles are Tirana and Durres which are the two largest centers with the largest number of population in the country. The criminal offenses that see as protagonist teens are theft and theft in collaboration followed by illegal weapons possession and trafficking and the use of narcotic drugs. Concerning is the fact that juveniles report that involvement in risky criminal behavior is related to their need for income from drugs.

Most of juveniles involved in criminal behavior comes mainly from urban areas. Their education is interrupted and adolescents find that there are some reasons where, with the highest percentage of emigration, they decide to leave school to migrate from their country into a European country for better life, learning difficulties as well as the exclusion for the unreasoned absences and economic problems, such as the inability to purchase books and clothing which are also presented as reasons for school interruption.

Adolescents have been in contact with marijuana, alcohol, tobacco, and other types of drugs very early between the 11-13 years old, a fact of great concern to every actor in our society, whether they are individuals or institutions. Teens admit that they find it very difficult to withdraw from drug use even though they appear to show a sort of awareness about the problems drugs have caused at a personal and interpersonal plan. These evidences should give more attention to the police, family, school and community structures in order to help youth for a better future.

\section{Acknowledgements}

This research did not receive any specific grant from funding agencies in the public commercial, or not-for-profit sectors.

The authors declare no competing interests. 


\section{References}

Agnew, R. (2006). General strain theory: Current status and directions for further research. In: F. T. Cullen, J. P. Wright, \& K. R. Blevins (Eds.), Taking stock: The status of criminological theory Advances in criminological theory (vol. 15, pp. 101-123). New Brunswick, NJ: Transaction Publishers.

Agnew, R. (2015). General strain theory and delinquency. The Handbook of Juvenile Delinquency and Juvenile Justice, 2, 239-256.

Akers, R. L., Sellers, C. S., \& Jennings, W. G. (2016). Criminological theories: Introduction, evaluation, and application (7th ed.). New York, NY: Oxford University Press.

Averdijk, M., Zirk-Sadowski, J., Ribeaud, D., \& Eisner, M. (2016). Long-term effects of two childhood psychosocial interventions on adolescent delinquency, substance use, and antisocial behavior: A cluster randomized controlled trial. Journal of Experimental Criminology, 12(1), 21-47.

Botvin, G., Baker, E., Dusenbury, L., Botvin, E., \& Diaz, T. (1995). Long-term follow-up results of a randomized drug-abuse prevention trial in a white middle class population. Journal of the American Medical Association, 273, 1106-1112.

Broadus, A. D., Hartje, J. A., Roget, N. A., Cahoon, K. L., \& Clinkinbeard, S. S. (2010). Attitudes about addiction: A national study of addiction educators. Journal of Drug Education, 4O(3), 281298.

Brook, S., Morojele, N.K., Pahl, K. \& Brook, D.W. (2006). Predictors of drug use among South African adolescents. Journal of Adolescent Health, 38(1), 26-34.

Brook, J. S., Lee, J. Y., Finch, S. J., Brown, E. N., \& Brook, D. W. (2013). Long-term consequences of membership in trajectory groups of delinquent behavior in an urban sample: Violence, drug use, interpersonal, and neighborhood attributes. Aggressive Behavior, 39(6), 440-452.

Burnhams, N. H. (2016). Statistical Trends in Substance Use in South Africa with a Focus on Young People, UNISA 2016 Youth Research Conference, Unisa.

Catalano, R. F., Haggerty, K. P., Fleming, C. B., Brewer, D. D., \& Gainey, R. R. (2002). Children of substance abusing parents: Current findings from the Focus on Families project. In: R. J. McMahon \& R. D. Peters (Eds.), The effects of parental dysfunction on children (pp. 179-204). New York: Kluwer Academic Press/Plenum Publishers.

Childs, K. K., \& Sullivan, C. J. (2013). Investigating the underlying structure and stability of problem behaviors across adolescence. Criminal Justice and Behavior, 4O(1), 57-79.

Choi, Y., He, M., Herrenkohl, T. I., Catalano, R. F., \& Toumbourou, J. W. (2012). Multiple identification and risks: Examination of peer factors across multiracial and single-race youth. Journal of Youth and Adolescence, 41, 847-862.

DeLisi, M., Angton, A., Behnken, M. P., \& Kusow, A. M. (2015). Do adolescent drug users fare the worst? Onset type, juvenile delinquency, and kriminal careers. International Journal of Offender Therapy and Comparative Criminology, 59(2), 180-195.

Eggert, L. L., Thompson, E. A., Herting, J. R., \& Randall, B. P. (2001). Reconnecting youth to prevent drug abuse, school dropout, and suicidal behaviors among high-risk youth. In: E. Wagner \& H. B. Waldron (Eds.), Innovations in adolescent substance abuse intervention (pp. 51-84). Oxford: Elsevier Science.

Ennett, S. T., Foshee, V. A., Bauman, K. E., Hussong, A., Cai, L., Reyes, H. L. M., \& DuRant, R. (2008). The social ecology of adolescent alcohol misuse. Child Development, 79(6), 1777-1791.

Francis, K. A. (2014). General strain theory, gender, and the conditioning influence of negative internalizing emotions on youth risk behaviors. Youth Violence and Juvenile Justice, 12, 58-76. 
Griffin, K. W., \& Gilbert J. B., (2011). Evidence-based interventions for preventing substance use disorders in adolescents, Child Adolesc Psychiatr Clin. N. America.

Kadalie, R. \& Thomas, M. (2013). Unemployment plays big role in substance abuse. Alcohol, drug use in $S A$ twice the global average. Citizen, April, 26 (1982). [Online] Available at: http://www.citizen.co.za (20 January 2018).

Kenneth et al., (2018). Association of mental health symptoms and peer behaviors with risk for substance use and condomless sex among youths in juvenile drug court, Journal of Child \& Adolescent Substance Abuse,_27(1).

Magidson, J. F., Janan, D., Kennedy, N. O., \& Kathleen, J. S. (2016). Psychosocial correlates of alcohol and other substance use among low-income adolescents in peri-urban Johannesburg, South Africa: A focus on gender differences. $J$ Health Psychology, March.

Matthews, I., Griggs, R., \& Caine, G. (1999). The experience review of interventions and programmes dealing with youth violence in urban schools in South Africa. An undertaking of the Independent Projects Trust. Retrieved 19 June 2016, from http://www.ipt.co.za/litreview.pdf.

Merrill, J. C., Kleber, H. D., Shwartz, M., Liu, H., \& Lewis, S. R. (1999). Cigarettes, alcohol, marijuana, other risk behaviors, and American youth. Drug and Alcohol Dependence, 56(3), 205-212.

Poundall, Th., Bogdanovica, I., \& Langley, T. (2018). A cross-sectional study of the impact of standardized tobacco packaging legislation on university students, Journal of Child \& Adolescent Substance Abuse, 27(1), 165-173.

Ramsoomar, L. (2015). Risk and protection: Alcohol use among urban youth within the birth to twenty. (Bt20) Cohort, Thesis Submitted in Fulfilment of The Requirements for the Degree of Doctor of Philosophy, Faculty of Health Sciences, University of the Witwatersrand, Johannesburg. 